\title{
CONNECTIONS BETWEEN SOCIODEMOGRAPHIC CHARACTERISTICS AND ATTITUDES TOWARDS EMPLOYEES WITH DISABILITIES
}

\author{
Author: \\ Emese Balázs-Földi (PhD.) \\ University of Debrecen, \\ Faculty of Child and Special Needs Education \\ (Hajdúböszörmény, Hungary) \\ E-mail adress of the first author: \\ balazs.foldi.emese@gmail.com
}

\author{
Lectors: \\ Erzsébet Gortka-Rákó (PhD.) \\ University of Debrecen, \\ Faculty of Child and Special Needs Education \\ (Hajdúböszörmény, Hungary) \\ Gyula Szabó (PhD.) \\ University of Debrecen, \\ Faculty of Child and Special Needs Education \\ (Hajdúböszörmény, Hungary)
}

Balázs-Földi E. (2019): Connections between sociodemographic characteristics and attitudes towards employees with disabilities. Különleges Bánásmód, 5. (1). 7-17. DOI 10.18458/KB.2019.1.7

\begin{abstract}
Since the annexation to the European Union exceptional attention has been directed to equal opportunities and equal treatment of disadvantaged social groups in Hungary too. The Hungarian state tries to ensure them first and foremost with legal tools. It is, however, not enough to result in lasting changes in the attitude of the society. Personal experiences, as well as, positive messages transmitted by others can produce a positive effect on the development of inclusive approaches. With respect to sociodemographic characteristics (e.g. gender, age, school qualification) investigations into this field suggest different research results. The questionnaire data collection took place in three districts of Hungary. The research was aimed at questioning two test groups, on one hand the employees of social institutions who mainly deal with disadvantaged persons, on the other hand the residents of the given districts, who have the knowledge and approach of an average citizen. The ingenuity of the research is put down to the fact that in Hungary there had never been a research to explore the attitudes of social employees. A total of 747 persons filled in the questionnaires, out of which 408 employees in social institutions and 339 district residents. This present study discloses the deeper connections of the research results which are observable between the two test groups' attitudes to persons with disabilities and sociodemographic characteristics. Its significance is crucial in identifying the characteristics of the colleague playing an actual role in the integration who, as a reference person, with his own personal involvement can promote the integration of disabled persons into workplace communities. In the research of attitudes three well-distinguished clusters were outlined, which were named as followings: accepting, uncertain/indifferent, rejecting. The study investigates what kind of sociodemographic characteristics the residents, and social workers who belong to the three clusters have. Do people who belong to the same cluster posses similar attributes in both test samples? What kind of attributes have the residents and social workers got who show a higher level of acceptance? According to the findings of the research the attitudes of the district residents differ in age, school qualification and personal experience, whereas in case of the social workers the difference in attitudes depends on age and school qualification.
\end{abstract}

Keywords: employee with disabilities, social worker, inclusive approach, labour market, employment Disciplines: Business and management, sociology

\section{Absztrakt \\ SZOCIODEMOGRÁFIAI JELLEMZŐK ÉS A FOGYATÉKOS MUNKAVÁLLALÓKKAL KAPCSOLATOS ATTITŰDÖK ÖSSZEFÜGGÉSEI \\ Az Európai Unióhoz való csatlakozás óta kiemelt figyelem irányul Magyarországon is a hátrányos helyzetű társadalmi csoportok esélyegyenlőségére, egyenlő bánásmódjára. A magyar állam ezek ér- vényesülését elsősorban jogi eszközök segítségével igyekszik biztosítani. Ezek azonban nem elegendőek ahhoz, hogy a társadalom szemléletében tartósan változásokat eredményezzenek. A befogadó attitűdök}


kialakulására pozitívan hatást gyakorolhatnak a személyes tapasztalatok, illetve a mások által közvetített pozitív üzenetek. Szociodemográfiai jellemzők (pl. nem, életkor, iskolai végzettség) tekintetében e tárgykörben született vizsgálatok eltérő kutatási eredményekről számolnak be. A kérdőíves felmérés adatgyújtése Magyarország három járásában valósult meg. A kutatás két csoport megkérdezésére irányult, egyrészt az elsősorban hátrányos helyzetû személyek nehézségeivel foglalkozó szociális intézmények munkavállalóira, másrészt a járásokban élő lakosokra, akik a társadalom átlagpolgárainak tájékozottságával, szemléletével rendelkeznek. A kutatás egyedisége, hogy hazánkban nem irányult még vizsgálat a szociális munkások attitűdjeinek feltárására. A kérdőíves kutatás válaszadóinak összlétszáma 747 fő, ebből 408 fó szociális intézményi dolgozó és 339 fó járási lakos. Jelen tanulmány a kutatás azokat a mélyebb összefüggéseket feltáró eredményeit mutatja be, amelyek e két vizsgálati csoport fogyatékos emberekkel kapcsolatos attitúdjei és szociodemográfiai sajátosságai között megfigyelhetők. Ennek jelentősége a beillesztésben ténylegesen szerepet vállaló munkatárs jellemzőinek beazonosítása szempontjából lényeges, aki mint referenciaszemély személyes szerepvállalásával elősegítheti a fogyatékos ember munkahelyi közösségekbe történő integrációját. A kutatásban az attitűdök kapcsán három, jól elkülöníthető klaszter rajzolódott ki, melyek a következő elnevezéseket kapták: elfogadó, bizonytalan/közömbös, elutasító. A tanulmány arra keresi a választ, hogy milyen szociodemográfiai jellemzőkkel rendelkeznek e három klaszterbe tartozó lakosok, illetve szociális munkások? Mindkét vizsgálati mintában hasonló jellegzetességgekkel rendelkeznek-e az egy klaszterbe tartozók? Milyen sajátosságokkal rendelkeznek a magasabb szintű befogadást mutató lakosok és szociális munkások? A kutatás eredményei szerint a járási állampolgárok esetében az attitúdök az életkor, az iskolai végzettség, és a személyes tapasztalatok alapján is eltéréseket mutatnak, míg a szociális munkásoknál csak az életkor és az iskolai végzettség szerint jelentkezik attitűdbeli különbség.

Kulcsszavak: fogyatékos munkavállaló, szociális munkás, befogadó szemlélet, munkaerőpiac, foglalkoztatás

Diszciplinák: gazdálkodás- és szervezéstudományok, szociológia

Expectations connected with the society and its subsystem regarding the realisation of equal opportunities and equal treatment of persons with disabilities have been present in the Hungarian jurisdiction since 1998 (Act XXVI of 1998 on the rights and equal opportunities of persons with disabilities). At the promulgation the law seemed novel and particular in Hungarian relations, since it declared the fulfilment of special rights of a disadvantaged social group and specified the aims that contribute to the realisation of their equal opportunities as well as its fields (e.g. healthcare, rehabilitation, employment). Another uniqueness of the law was that it specified a deadline to the fulfilment of the aims, such as the discontinuance of boarding institutions with large number of residents and their transformation into a system of residential homes, or the achievement of accessibility. Later these deadlines needed to be extended again and again as they proved to be unachievable. It highlighted the problem that the high-standard theoretical expectations of the legislator cannot be attained without an actual paradigm shift in the approach of the society, those concerned, and their direct social surroundings (relatives, pedagoges, caregivers, helpers, colleagues, employers, etc.) (Vekerdy-Nagy \& Rákó, 2017). Employment is one of the fields of equal opportunities which supports the integration of persons with disabilities. The sheltered employment model facilitates the employment of persons with disabilities, which is an efficient strategy to prepare the colleagues and disabled employees for the labour market inclusion (Rákó, 2012). The integrated employment of persons with disabilities is established by the accepting approach of the labour market's participants (employers, colleagues). The basis of the change in approach is the attitude which regards the person with disability not as a hindered person who lacks skills, but rather as a person with abilities who is able to learn, work, and fulfil his social roles. In the first part, the study lays foundations of the attitude concept and presents the methodology, then the results and findings of previous researches on sociodemographic and other factors that play a role in the development of attitudes.

It is followed by the overview of the findings of research exploring the attitudes of residents and workers in social institutions in three districts in Hungary. 
The main aim of the study is to explore what kind of factors affect the attitudes and what sort of characteristics those residents and social workers have who demonstrate a higher level of acceptance. A further objective is to find out what characterises the professionals as well as the citizens who have an accepting attitude to persons with disabilities and therefore they can actually take an effective role in the integration and inclusion of persons with disabilities.

\section{The attitude}

In the science of psychology there are many approaches to define the concept of the attitude. Among them one of the best known and most often used definition was published by Allport in 1935. "The attitude is a mental and neutral state of readiness, organised through experience, exerting a directive or dynamic influence upan an individual's response to all objects and situations with which it is related." (by Allport (1935) quoted by Halász \& Hunyadi \&Marton, 1979 p.49). Thomas and Znanieczki (1918) defined the attitude as mental processes which determine the person's behaviour and acts. Attitudes are positive or negative manifestations towards objects, people, situations (Atkinson et al., 1997). The attitude is valuing relation, a state of mind toward an object which helps to find one's way in the society (Attkinson et al., 1997; Mező, 2008; Maio \& Haddock, 2010). Binet (1911) suggests that the attitude consists of conscious and unconscious parts (Halász \& Hunyadi \& Marton, 1979 p.11).

The attitude is resulted by learning and can be based on personal experiences or taken over from others (e.g. a reference person). Attitudes are constant, changing them is a slow process, as they are based on experience and are connected to the individual's personal values (Csepeli, 2010; Csepeli, 2015). Sensitisation trainings may further the attitude shaping, as they offer a great opportunity on one hand to enhance knowledge on the real-life situation of persons with disabilities by providing information, on the other hand by creating a direct contact with them, and this way the existence of disability becomes a personal experience. Attitudes consist of three components (Budavári-Takács, 2011).

The first element is the conceptual or cognitive component, which appears in opinions or thoughts. The second part is the emotional or mental component, which can range from acceptance to refusal (from the positive to the negative relation). The third one is the behavioural or conative component, which can be observed in actual activity and behaviour. A speciel field in the social research is the measurement of attitudes.

A particular research method is needed to become acquainted with attitudes, the best-known measurement tools are the Bogardas scale, the Likert scale and Osgood's semantic differential scale (Ferge \& Cseh-Szombathy, 1975; Babbie, 2000).

\section{Presentation of research history}

Firstly, researches focused on the examination of attitudes towards persons from different nationalities, but nowadays researches of attitudes to other social groups such as disabled persons are comprehensively presented in the fields of various social sciences. The relation to disability, the familiarisation with its particularities have become especially important in the viewpoint of social inclusion therefore in the affected scientific fields i.e. in pedagogy and employment there have been significant researches into this topic.

Researches carried out in the domain of pedagogy primarily aimed to explore the attitudes of pedagoges, carers, and schoolmates who played part in the inclusion (Majoros, 2009; Némethné Tóth, 2009; Pető \& Ceglédi, 2012; Costello \& Boyle, 2013).

In the course of the research social background information was also examined such as the role of gender, age, school qualification. According to the findings of the research the attitude differences by gender are not unambiguous.

However, Boer (2011), Avramidis \& Norwick (2002), Szabó (2016) and Huszár et al. (2018) discovered divergence between the attitudes of female and male respondents: women seem more accepting than men regarding children with disabilities, on the other hand Pongrácz (2013) did not find such differences in his research. The attitudes show differences based on the age in the research of Forlin et al. (2009) and Avramidis \& Norwick (2002), they found the younger generations more accepting, but the researches of Ellins - Porter (2005) did not confirm it.

Based on school qualification Horváthné Morvay (2006) did not find any differences, but there were differences in case of having special knowledge, whereas according to Sharma et al. (2006), Hollins (2011) higher school qualification can positively influence the attitudes. Regarding studies based on the research results of Vignes et al. $(2008,2009)$ it can be stated that previous knowledge on disability can put a positive influence on attitudes.

Allport (1979) pointed out the role of personal contact in dissolving prejudices. It was supported by research results that personal experiences and 
contact with disabled persons can promote the dissolving stereotypes and the creation of positive attitudes (Szegő, 2008; Némethné Tóth, 2009; Szabó, 2016).

Another main field of inclusion is employment, and its accepting approach is indispensable for the social catching-up of persons with disabilities and the improvement of their life quality.

Researches in this aspect primarily focused on the acquaintance with the attitudes of organisational leaders and HR professionals. These researches examine the matter of employment in case of persons with disabilities and a reduced work capacity. Mapping the role of sociodemographic background factors has not been in the focus of the research, but in connection with the examination of the leaders' attitudes the attitude shaping effect of personal connections and work experience was pointed out. (Fuqua et al., 1984; Blanck, 1998; Unger, 2002).

There are not so many available research results on the attitudes of social employees. It is interesting as the social profession is a special field of art sciences which first and foremost aims to deal with social problems and support the people in need. In order to achieve these goals, those who exercise a social profession have to meet high professional ethical requirements, such as tolerance, sensitivity to social problems, empathy, accepting attitude, etc. (Soós, 2005). Eubank (2010) researched the attitudes of social employees towards persons with physical disability. He stated that social professionals approached the problems of disabled persons from the perspective of hindrances and lack of abilities, and their attitudes were not more positive towards them.

Selvamani \& Rajan (2017) explored the attitudes of social employee students. Based on their research results, two-third of the students expressed basically positive attitudes to persons with disabilities, nevertheless they did not consider their employment an important factor.

In summary, based on the review of the specialist literature it could be stated that regarding the results of the attitude research the following sociological background factors may influence the attitudes: gender, age, school qualification, preliminary or special knowledge on disability, personal experiences, and work connections.

DATABASE AND METHOD OF THE RESEARCH

The questionnaire data collection took place in three districts of Hungary (Hajdúnánás, Haj- dúböszörmény, Derecske). The research was aimed at questioning two test groups, on one hand the employees of social institutions who mainly deal with disadvantaged persons, on the other hand the residents of the given districts, who have the knowledge and approach of an average citizen. The uniqueness of the examination compared to previous research is given by the fact that the subject is not approached from the perspective of persons with disability and a reduced work capacity, or of employers, but the work and employment of persons with disability and a reduced work capacity is examined from the viewpoint of coworkers. The primary aim of the examination was to explore the attitudes of the two test groups towards employees with disability and a reduced work capacity. In the course of the survey a total of 309 residents and 408 persons from the institutions filled in the questionnaire. The assemblage of the residential sample was not based on probability quota sampling. Employees of social institutions run by the government or local government were involved in the sample of social institution employees, based on voluntary participation $75-80$ percent of them filled in the questionnaires.

The present study focuses on the presentation of research results that explore the connections in attitudes and sociodemographic characteristics that the surveyed groups have towards disabled employees. To examine the results of the research cluster analysis was conducted. Based on the average values of the cluster analysis the residents and the social employees could be classified according to their attitude to employees with disabilities into three clusters (Balázs-Földi, 2018). Those who belonged to the first cluster were called "accepting" as in every question they related to disabled persons in an accepting, postive way.

The members of the "uncertain/indifferent" cluster do not openly express their opinion that is they suggest caution, uncertainty and indifference. Those who belong to the "rejecting" cluster are rejective and negative towards persons with disabilities. The study evaluates the results based on the following factors: age, school qualification, preliminary knowledge gained on disability, and direct experience with disabled persons.

\section{Characteristics of test samples}

The gender distribution of social workers shows that this profession is becoming a female preserve. $88.5 \%$ of the employees are women and $11.5 \%$ of them are men. Based on the age distribution it seems that most of them are over 35 years of age, 
$32 \%$ of them fell into the 36-45 age group, 35.3\% into the 46-55 age group, the younger age group is much less represented (Figure 1).

$16.4 \%$ of the social employees have elementary qualification, $56.9 \%$ have secondary qualification and $26.7 \%$ have tertiary qualification.

The gender distribution of the district residents: $40.8 \%$ male and $59.2 \%$ female. The age distribution of the residential respondents is more uniform compared to the respondents of social institutions. The largest proportion fell into the 26-35 age group (21.2\%) and into the $36-45$ age group (21.8\%) (Figure 1). 26.2\% of the residents have elementary qualification, $45.2 \%$ have secondary qualification, $28.6 \%$ have tertiary qualification.

$75.1 \%$ of the employees in social institutions gained preliminary knowledge related to disability, whereas it is only $34 \%$ in case of district residents.
Much fewer people in both groups have work experience or personal experience, $43.7 \%$ of social employees and $22.4 \%$ of residential respondents said to have had such involvement (Figure 2).

Based on which cluster they belong to, social employees and district residents have the following distribution. Regarding preliminary assumptions, we would expect social professionals to have a higher level of acceptance, meanwhile we would expect district residents to have a lower level of acceptance, but the results of cluster analysis did not confirm it clearly. More than half of the social employees $(55.8 \%)$ belong to the uncertain/indifferent category, while $29 \%$ can be listed in the accepting and $15 \%$ in the rejecting cluster. In case of the district residents the proportion of those $(35.7 \%)$ who are cautious is lower, they express their opinion more openly, $37.3 \%$ of them belong to the rejecting and $27.1 \%$ to the accepting cluster (Figure 3).

Figure 1: Age group distribution of respondent social employees and district residents (\%). (Source: Compiled by the author)

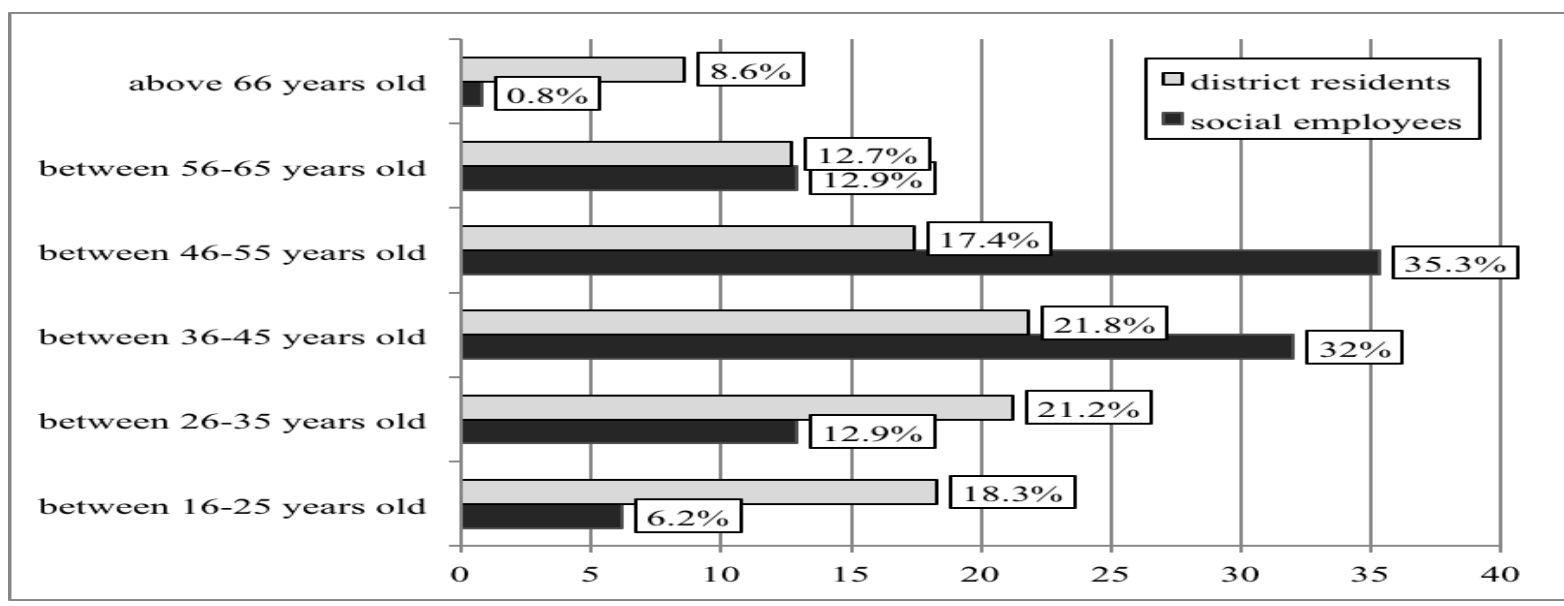

Figure 2: Distribution of social employees and district residents based on work experience and preliminary knowledge (\%). (Source: Compiled by the author)

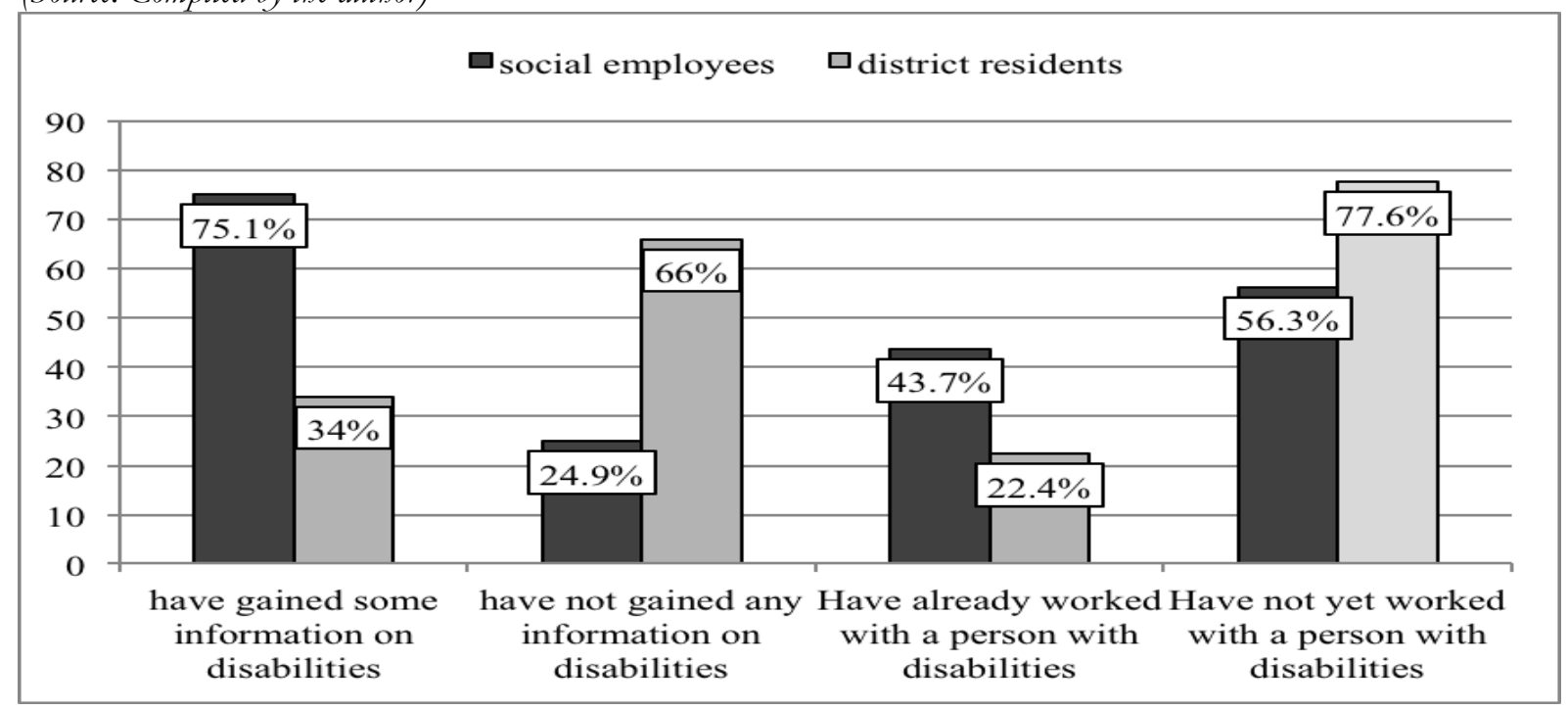


Figure 3: Distribution of social employees and district residents based on clusters which they belong to (\%). (Source: Compiled by the author)

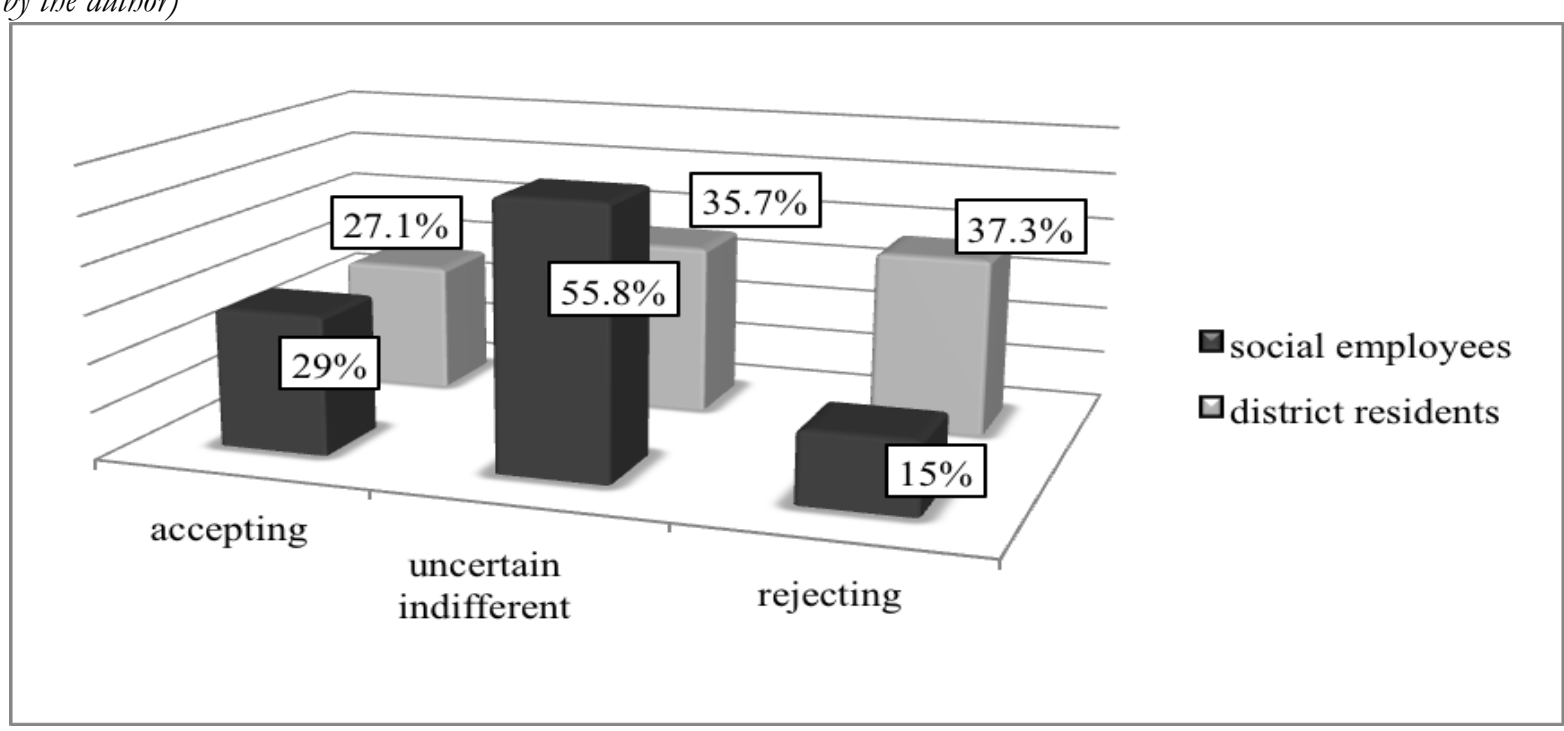

\section{RESEARCH RESULTS}

Based on the age of the respondent district residents there are significant differences regarding the clusters they belong to. One-third (34.1\%) of those who can be listed in the accepting cluster fall into the 36-45 age group, $18.8 \%$ into the $26-35$ age group. The largest scale rejection was demonstrated by $46-55$ age group $(23.9 \%)$ and $16-25$ age group $(22.2 \%)$. Indifference features mainly the $26-$ 35 age group (25\%) and the 56-65 age group $(19.6 \%)$, they demonstrate caution and uncertainty in the acceptance of persons with disabilities. However, in case of the latter age group it is important to stress that the age group over 66 years of age which follows them are accepting and they express their opinion more openly, fewer of them belong to the uncertain/indifferent cluster (5.4\%), while the proportion of the those rejecting is the same size as in the 56-65 age group (9.4\%) (Figure 4).

Amongst social employees also the 36-45 age group demonstrates the highest level of acceptance $(44.2 \%)$, whereas the $46-55$ age group the lowest (40\% is the proportion of those who are rejecting) (Figure 5). The rejecting attitude of this latter age group is supported by the fact that besides the high proportion of rejection $(40 \%)$ the proportion of those who belong to the uncertain/indifferent cluster is also high (42.2\%). A common characteristic of the 16-25 age group, the 26-35 age group and the 36-45 age group is that their proportion in the accepting cluster is higher, meanwhile that of in the uncertain/indifferent cluster and in the rejecting cluster is lower. However, in the age group above
46 years of age the contrary tendency is visible that is the proportion in the accepting cluster is lower, while the proportion in the uncertain/indifferent and in the rejecting clusters is higher.(Figure 5).

An interesting difference in the aspect of the two samples is that in case of the district residents, with the exception of the 36-45 age group and those above 66 years of age, in all age groups the proportion is lower in the accepting cluster and higher in the uncertain/indifferent or rejecting clusters. In case of employees of social institutions the younger age groups (16-45 years of age) manifest accepting attitudes, while the older age groups (above 46 years of age) have more rejecting attitudes.

In summary, in the aspect of age the results suggest that in both test samples those who have an accepting attitude belong to the 36-45 age group, they are the ones who probably thanks to their real-life experience and approach have the most open attitude towards persons with disabilities.

Based on school qualification, districts residents with tertiary education have the highest proportion in the accepting cluster (45.8\%). In the uncertain/indifferent and in the rejecting clusters district residents with secondary education represent the highest proportion. Consequently, they are less accepting regarding persons with disabilities. Amongst social employees belonging to the accepting cluster are those with secondary education $(57.4 \%)$ and the lowest proportion (7.4\%) has basic education. Based on the results we can draw the conclusion that in the rejecting cluster the proportion of those who have basic education is outstanding $(31.4 \%)$ (Figure 6). 
Figure 4: Clusters of district residents based on age (\%). (Source: Compiled by the author)

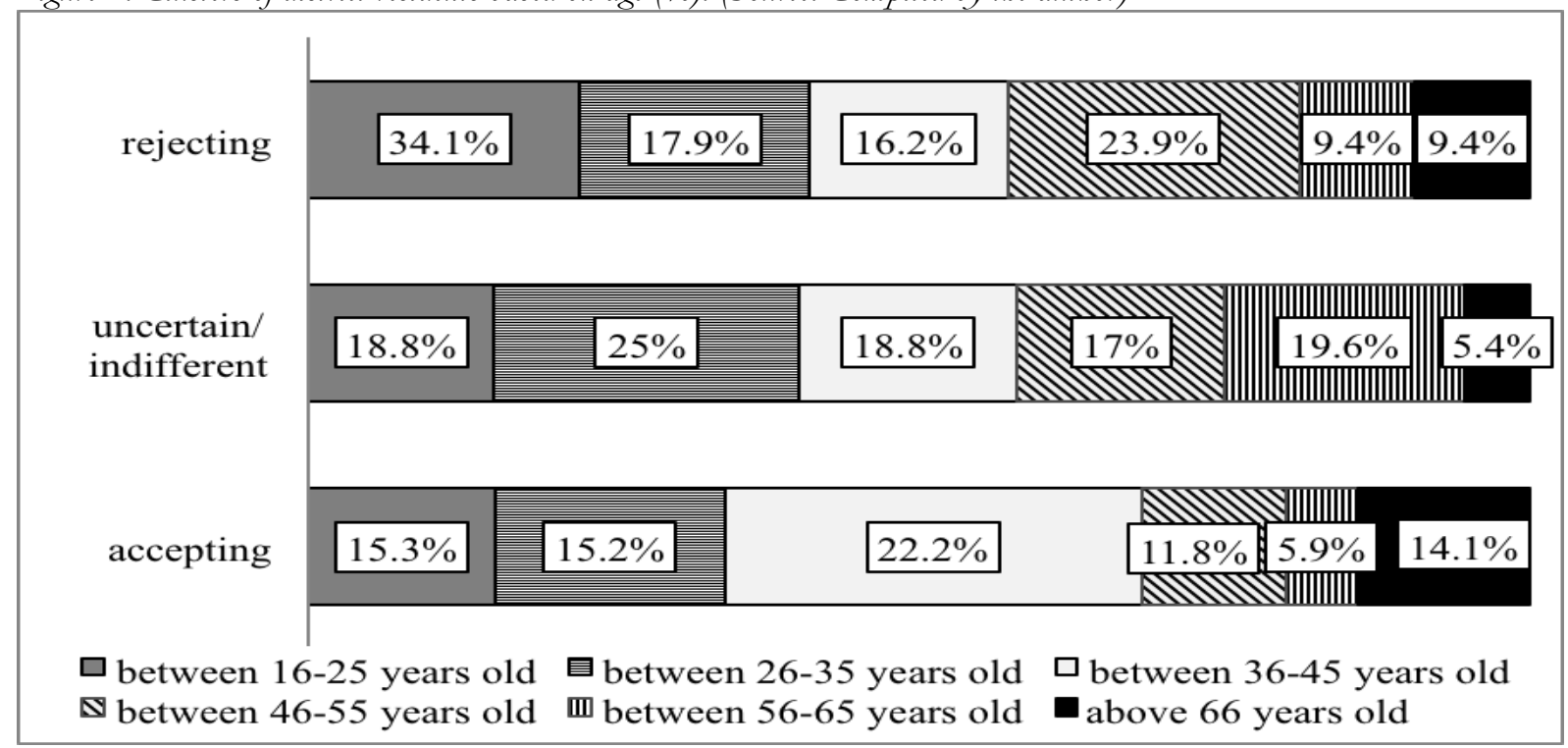

Figure 5: Clusters of social employees based on age (\%). (Source: Compiled by the author)

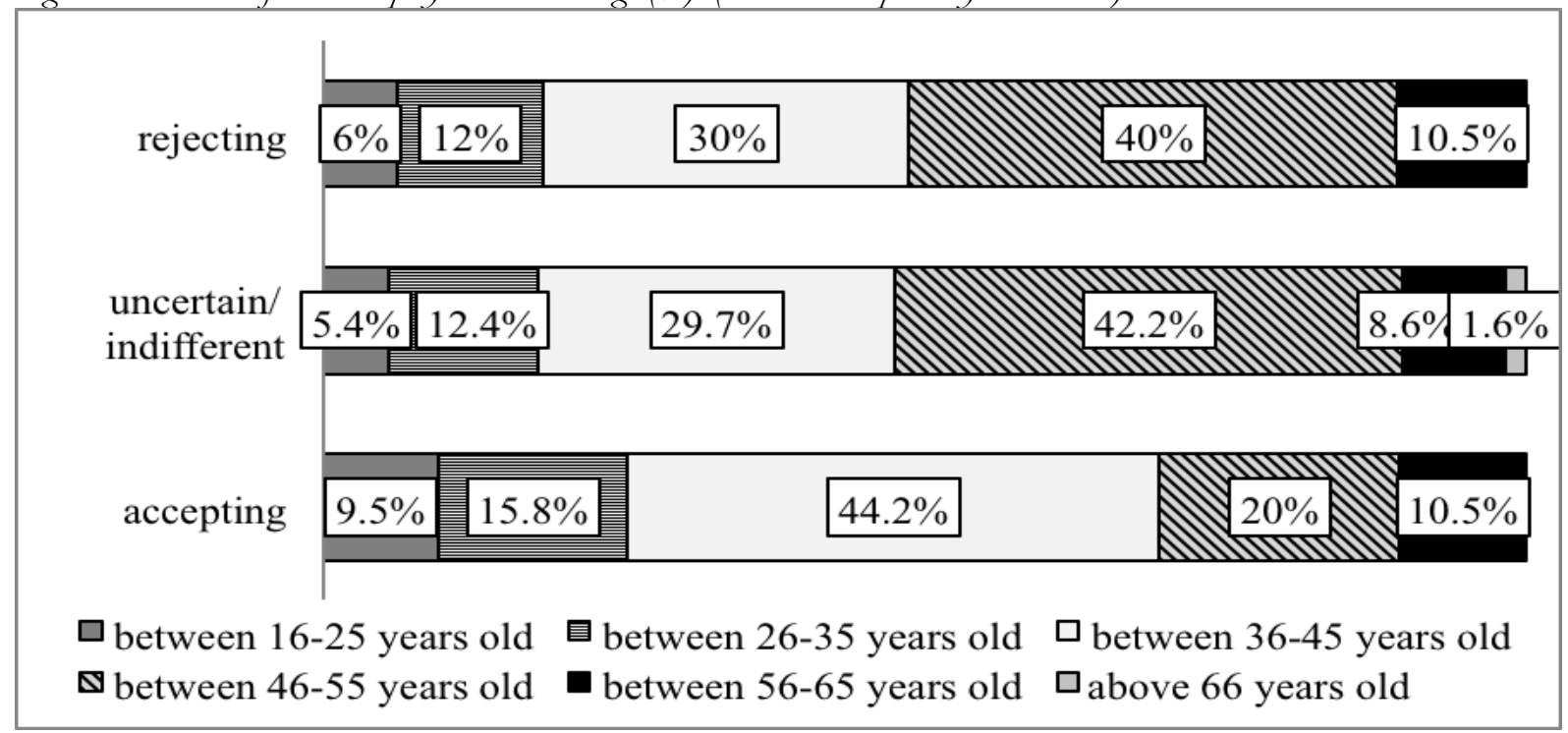

The results of Figure 6 suggest that the rise in school education positively influences the accepting attitudes. While in the rejecting cluster there is in both samples a higher proportion of those who have basic education, those with tertiary education have rather accepting attitudes towards persons with disabilities and their proportion is lower in the rejecting or uncertain/indifferent clusters.

Based on results of previous studies, we can assume that persons in the accepting cluster have gained preliminary knowledge, whereas the majority of the members in the rejecting cluster has no preliminary knowledge. However, the study results did not show any significant correlation in case of either test groups. Nevertheless, it can be ascertained as a tendency that the proportion of those with preliminary knowledge on disability was higher in the accepting cluster $(83 \%$ in case of social employees and $43.5 \%$ by district residents), but significant difference could not be established amongst the respondents belonging to the accepting, uncertain/indifferent or rejecting clusters.

Work relationship with disabled persons influences the accepting attitudes positively. Based on research results amongst persons who belong to the accepting cluster the proportion of those who 
have already worked together with a disabled person is higher. In the residential sample one-third $(30.6 \%)$ of the people in the accepting cluster, $10.7 \%$ of the uncertain/indifferent cluster and $24.8 \%$ of the rejecting cluster have work experience with persons with disabilities. The caution of the uncertain/indifferent cluster comes from the fact that $83 \%$ of them have never worked with persons with disabilities and therefore they have not got any real-life experience. $61.2 \%$ of those belonging to the accepting cluster and 68.4\% of those from the rejecting cluster have not had personal contact with a person with disabilities. Based on the results it can be clearly established that personal contacts have a positive impact on the accepting attitudes (Figure 7).
In case of employees working in social institutions a significant difference based on work experience was not established. It is, however, surprising that the residential findings are not confirmed even as a tendency, as in case of the social employees the majority of those who belong to the accepting cluster $(54.6 \%)$ have never worked together with a person with disabilities and the same applies to those $(51 \%)$ with rejecting attitudes. Accordingly, the rejecting cluster of social employees has more real-life experience $(46.9 \%)$ than social employees in the accepting cluster $(44.3 \%)$. This result demonstrates a completely opposite tendency compared to the residential sample.

Figure 6: Clusters of social employees and district residents based on school qualification (\%). (Source: Compiled by the author)

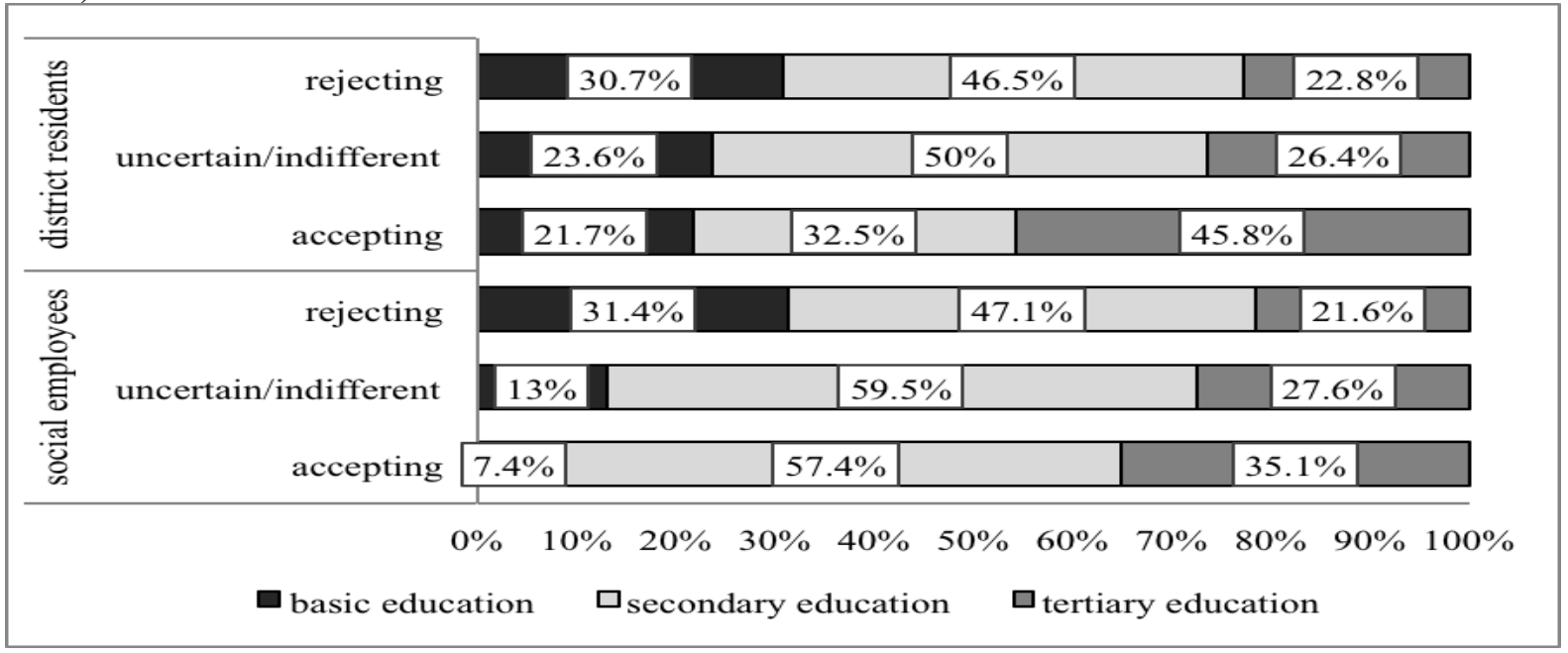

Figure 7: Clusters of district residents based on work experience (\%). (Source: Compiled by the author)

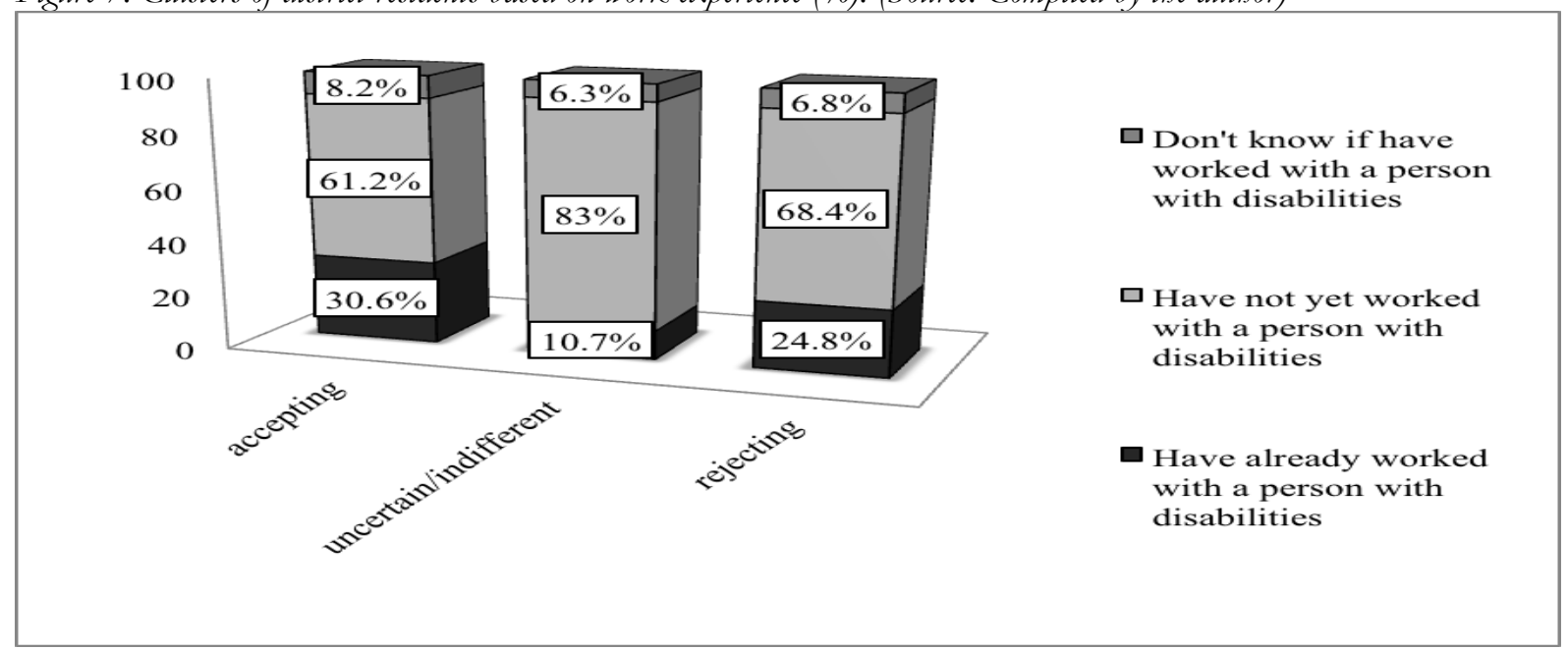




\section{Conclusions}

The labour market employment of persons with disabilities in Hungary has significant obstacles. The basis of equal employment and comprehensive integration could be created by accepting attitudes towards persons with disabilities. Therefore it is important to take into consideration the factors that show a positive correlation to the creation and development of the accepting attitudes. The results of previous research suggest that gender, school qualification, age segment, preliminary special knowledge, real-life experience can result in different attitudes.

Based on the findings of this present research, it can be established that amongst the attitudes of the district residents there are differences with regard to their school qualification, age, and personal experience, while in case of social employees school qualification and age result in different attitudes. In the aspect of preliminarily gained knowledge there was no significant difference either in the attitudes of district residents or that of social employees. By all means it is thoughtprovoking, as one principal element of the social sensitisation is to increase the knowledge related to the target group, by itself it does not seem to be enough, though, to permanently establish a proper openness and sensitivity towards social problems.

The result of the examination also points out that an important circumstance in the transfer of knowledge is in what approach or perspective the residents and the social professionals are informed about the real-life situation of persons with disabilities. Does the information approach the life situation of persons with disabilities from the aspect of the social model and focus on the strengths, possibilities, as well as the elimination of social barriers; or from the medical model's point of view focusing on the lack of abilities?

The research findings based on school qualification suggest that higher level qualification results in the strengthening of accepting attitudes. In both test groups those with tertiary qualification are characterised by a higher level of acceptance, and those with elementary qualification show a lower level of accepting approach. It highlights the fact that tertiary education, although it does not expediently aim to introduce social problems, facilitates the development of a boarder view and a more tolerant approach. It raises the possibility that the higher school qualification the citizens have, the more open, the more tolerant social approach can be developed.

As regards the age segment, based on the research results it can be concluded that both amongst district residents and employees of social institutions the 36-45 age group shows the highest level of acceptance. From the point of view of the labour market this age group is the most active, they are already in possession of real-life experience and knowledge and they relate to disabled persons - and probably to other disadvantaged groups too - with openness, tolerance, empathy, acceptance.

Personal experience with persons with disabilities amongst the district residents influences the accepting approach in a positive way. Those who have had the chance to enter into personal contact with disabled persons belong to the accepting cluster in higher proportion. On the other hand, those without such experience approach persons with disabilities in a more cautious, more uncertain and more rejecting way. The research conclusion can be drawn that the highest level of acceptance was manifested by the residents who fall into the 36-45 age group, have tertiary qualification, and personal experience, they are the ones who can most effectively promote the integration of persons with disabilities, the validation of their human rights, as they possess adequate openness and sensitivity towards social problems.

The most interesting results of the study, however, concern to the attitudes of the employees in social institutions. Neither preliminary knowledge, nor real-life experience resulted in significant differences in the attitudes of the employees in social institutions. They have the same attitude independently whether they have received special knowledge, information, or they have direct experience with persons with disabilities.

In the background may be the fact that thanks to their profession they are genuinely more open, more accepting, more tolerant towards disadvantaged persons, therefore other factors do not influence their approach significantly. Then again, the question arises in the light of the results why there is not a more striking positive difference between the attitudes of the citizens and the social employees based on either their age or their school qualification. The answer may lies in the fact that the training of social employees basically concentrates on the problems of the clients and the possible solutions for them.

Their professional attitude is rather featured by a problem-oriented approach (medical approach), while focusing on the strengths, existing abilities, and functions remains in the background. However, it serves rather the strengthening of the rejecting, or uncertain/indifferent attitudes. 


\section{REFERENCES}

Allport, G. W. (1979): Az attitűdök. In: Halász, L.., Hunyady, Gy., \& Marton, L. M. (szerk.): Az attitüd pszichológiai kutatásának kérdései. Akadémiai Kiadó. Budapest. 41-57.

Attkinson, R., Smith, E., \& Daryl, B. (1997): Pszichológia. Osiris, Budapest.

Avramidis, E. \& Norwich, H. (2002): Teachers' attitudes towards integration/inclusion: a review of the literature. European Journal of Special Needs Education. 17(2). 47-129.

Babbie, E. (2000): A társadalomtudományi kutatás gyakorlata. Balassi Kiadó. Budapest.

Balázs-Földi, E. (2018). Fogyatékos és megváltozott munkaképességü munkavállalókeal kapcsolatos attitüdök. Ihrig Károly Gazdálkodás- és Szervezéstudományok Doktori Iskola. DEA. 135.

Blanck, P. D. (1998): Job Placement for Employees with Disabilities - Manpower Leads the Way. Employment Relations Today. 25. 57-65.

Budavári-Takács, I. (2011): A tanácsadás sqociálpsrichológiája. Szent István Egyetem. Gödöllō.

Costello, S., \& Boyle, C. (2013): Pre-service secondary teachers' attitudes towards inclusive education. Australian Journal of Teacher Education. 38 (4). 129-143.

Csepeli, Gy. (2010): Szociálpszichológia. Osiris, Budapest.

Csepeli, Gy. (2015): A szervezkedó ember. A szervezeti élet szociálpszichológiaja. Kossuth Kiadó. Budapest.

Eubank, A. C. (2010): Assessment of social workers attitudes towards people with phisical disability. University of Tennessee. Knoxwille.

Ferge, Zs., \& Cseh-Szombathy, L. (1975): A szociológiai felvétel módsz̧erei. Közgazdasági és Jogi Könyvkiadó. Budapest.

Forlin, C., Loreman, T., Sharma, U., \& Earle, C. (2009): Demographic differences in changing pre- service teachers' attitudes, sentiments and concerns about inclusive education. International Journal of Inclusive Education. 13(2). 195-209.

Fuqua, D. R., Rathbun, M., \& Gade, E. M. (1984): A comparison of employer attitudes toward the worker. Journal of Applied Rebabilitation Counseling, 15 (1), 40-43.

Halász, L., Hunyady, Gy., \& Marton, L. M. (szerk.) (1979): Az attitǘd pszichológiai kutatásának kérdései. Akadémiai Kiadó, Budapest

Hollins, E. R. (2011): Teacher Preparation For Quality Teaching. Journal of Teacher Education. 62(4). 395-407.

Horváthné Moldvay, I. (2006): Attitűdkutatás pedagógusok körében az integrált nevelésről.
Iskolakultura. 10. 81-97

Huszár, Z., Várnagy, P., Zádori, I., Nemeskéri, Zs., \& Pankász, B. (2018): Tolerancia és érzékenység. Tudásmenedzsment, 19(1). 42-51.

Maio, G. R., \& Haddock, G. (2010): The Psychologie Attitudes and Attitude Change. SAGE Publications Ltd. London.

Majoros, A. E. (2009): Semmirekellők, naplopók. avagy az iskolai integráció egy délmagyarországi kistérségben. Gyógypedagógiai Szemle. XXXVII. (4).239-253.

Mező, F. (2008): Az attitűdváltozást, - konzerválását célzó lélektani műveletek (PSYOPS). Hadtudomány. 3-4. 71-82.

Némethné Tóth, Á. (2009): Tanári attitüdök és inklúzív nevelés. Magyar Pedagógia, 109 (2). 105120.

Pető, I., \& Ceglédi, T. (2012): A pedagógusok SNIvel szembeni attitúdje SACIE-vel mérve. Iskolakultíra, 22. (11).66-82.

Pongrácz, K. (2013): Többségi általános iskolások sajátos nevelési igényu" gyermekekkel szembeni attitüdjének vizsgálata. Gyógypedagógiai S remle, 41. (3.) 197-207.

Selvamani, R., \& Rajan, D. (2017): Social workersattitudes towards persons with disability. $I n$ ternational Journal of Management Research \& Review. 71(9). 933-940.

Sharma, U., Forlin, C., Loreman, T., \& Earle, C. (2006): Pre-service teachers' attitudes, concerns and sentimenta about inclusive education: an international comparison of the novice preservice teachers. International Journal of Inclusive Education. 21(2). 80-93.

Soós, Zs. (2005): A sqociális munka alapjai. Comenius Bt. Pécs.

Szabó, D. (2016): Látlelet a pedagógusok a befogadó nevelés-oktatáshoz való hozzáállása. Iskolakultúra, 26. (4.) 21-36.

Szegő, Á. (2008): Pedagógusok attitüdje az integrált oktatással kapcsolatban. Alkalmaz̧ott pszichológia, 10. (3-4).21-34.

Rákó, E. (2012): A megváltozott munkaképességú személyek foglalkoztatásának támogatása, a komplex rehabilitáció és intézményei. In Rákó E., \& Szűcs E.: Munkaerö-piaci helyzetkép Magyarországon és Romániában. Belvedere-Meridionale, Szeged. 54-74.

Thomas, W. I., \& Znaniecki, F. (1918): The polish peasant in Europe and America. Badger, Boston, MA.

Unger, D. D. (2002): Employers' attitudes toward persons with disabilities in the workforce: myths or realities? Focus on Autism and Other De- 
velopmental Disabilities,17. (1) Spring. PRO-ED. Inc.

Vaz, S. et al. (2015): Factors Associated with Primary School Teachers' Attitudes Towards the Inclusion of Students with Disabilities. PLOS ONE. https://doi.org/10.1371/journal.pone.0137002, letöltés ideje: 2019. január 22.

Vekerdy-Nagy Zs., \& Rákó, E. (2017): A fogyatékosság elfogadottsága ma a világban és hazánkban. In: Vekerdy-Nagy, Zs.: Bizonyitékokon alapuló rehabilitációs medicina. Medicina Könyvkiadó. Budapest. 25-47.

Vignes, C., Coley, N., Grandjean, H., Godeau, E, \& Arnoud, C. (2008): Measuring children's attitudes towards peers with disabilities: A review of instruments. Developmental Medicine Child Neurology, 50. 182-189.

Vignes, C., Godeau, E., Sentenac, M., Coley, N., Navarro, F., Grandjean, H., \& Arnaud, C. (2009): Determinants of students' attitudes towards peers with disabilities. Development Medicine and Child Neurology, 51(6).473-479.

Ellins, J., \& Porter, J. (2005): Departmental differences in attitudes to special educational needs in the secondary school. British Journal of Special Education. 32. (4).188-195. 